\title{
The Life-Cycle Assessment of Greenhouse Gas Emissions and Life-Cycle Costs of E-Waste Management in Thailand
}

\author{
Aweewan Mangmeechai ( $\nabla$ aweewan.m@nida.ac.th ) \\ National institute of Development Administration https://orcid.org/0000-0002-2201-3617
}

\section{Research}

Keywords: LCA, LCC, E-waste management, Circular economy

Posted Date: October 18th, 2021

DOI: https://doi.org/10.21203/rs.3.rs-960294/v1

License: (9) (i) This work is licensed under a Creative Commons Attribution 4.0 International License. Read Full License

Version of Record: A version of this preprint was published at Sustainable Environment Research on March 14th, 2022. See the published version at https://doi.org/10.1186/s42834-022-00126-x. 


\begin{abstract}
There is no clear direction in the management of electrical and electronic waste products (e-waste), as there are no regulations on ways to do so. This research attempts to understand the trade-off between economic value and environmental effects of the current disposal of e-waste to find ways to optimize waste management, focusing on cellphones, television CRTs, desktop computers, and air conditioners. A Life Cycle Assessment (LCA) is a tool that can analyze various influences, e.g., environmental, costs, and value added. Under the e-waste management status quo, most household e-wastes are kept in houses because owners do not know where to discard them. In addition, informal sectors, such as domestic farmers or workers, have been involved actively for more than a decade, leading to poor management standards for both health and the environment. The logistics are inefficient because the dismantling communities and recycling industry are far apart. Most e-waste is generated, and most recycling industries are located, in the Central region (the richest areas), while the dismantling communities are located in the Northeastern region (the poorest areas). Further, LCA and LCC of e-waste are sensitive to transportation, and not all e-waste parts can be recycled within the country. High-tech mineral extraction cannot be practiced in the country, and thus, circuit boards and batteries are exported for recycling. To promote a circular economy, e-waste management regulations should be implemented and a full recycling industry should be established in the country.
\end{abstract}

\title{
1. Introduction
}

Thailand has been facing many challenges, as the country lacks accurate information about e-waste, from the amount of waste generated per year until the end of its life. In addition, the country still has no legislation on e-waste management, and thus, it is difficult to collect household e-waste for recycling. Importantly, local authorities still are unready to manage household waste [1, 2].

The amount of e-waste of all types was estimated to be approximately $357,000,384,233$, and 421,335 tons in 2012, 2015, and 2019, respectively, and this trend is likely to increase by more than 40 percent over the next 10 years $[3,4]$. In addition, according to a survey of household consumers' behavior in dealing with e-waste, the Pollution Control Department (2017) reported that 51.3 percent of ewaste owners sell their devices to second-hand shops, 25.3 percent keep them at home, 15.6 percent discard them with general waste, and 7.8 percent do something else.

Under the current status quo, because no fee is collected from producers or consumers, the market determines the collection system. In addition, informal sectors have been involved actively in separating and dismantling e-waste, which has led to inefficient collection and disposal systems.

These informal sectors are scattered throughout the country, particularly in the North-eastern region (Daeng Yai and Ban Pao subdistricts, Buriram province). They include approximately 347 families that separate and dismantle 383 tons of e-waste per week [5].

The key to the success of e-waste management is its economic function (cost effectiveness), environmental effects, social awareness, and technological aspects [6]. Importantly, it is impossible to design effective e-waste policies if the government does not have information about e-waste and its distribution flow. Life cycle assessment (LCA) can evaluate the environmental performance of e-waste management activities [7] [8] and a financial life cycle costs (LCC) is a tool used to analyze the economic effects of an LCA system and can be viewed as an analytic tool parallel to an LCA. The combined use of LCA and LCC is imperative to assess the sustainability of a product or product system in the economy [9].

Accordingly, the objectives of this study are to 1) study and estimate the LCA of greenhouse gas (GHGs) and LCC of household ewaste, focusing on the top 4 types of e-waste discarded in the country, TV (CRTs), desktop computers, air conditioners, and mobile phones, and 2) provide policy recommendations for e-waste management. This study will contribute to understanding the status of ewaste management in Thailand and the trade-off between e-waste's environmental and economic aspects to provide better disposal practices. Hence, the results of this study will be valuable for the entire e-waste treatment industry.

\section{Background}

\subsection{Estimated total amount of e-waste generated in Thailand}

Page 2/15 
Some studies have reported government agencies', such as the Pollution Control Department and the Department of Industrial Works, e-waste estimates. The estimation of the amount of waste products produced in 2019 were provided in various reports [4, 10-14]. Each study used different estimation methods, such that the results yielded different numbers. The estimated number of the 4 types of waste products (mobile phones, desktop computers, air conditioners, and televisions) generated in 2019 were approximately $89,499-257,567$ tons: Of these, there were 1) 1,343-2,875 tons or 10.74-23.00 million mobile phones; 2 ) $16,250-58,178$ tons or $1.25-$ 4.47 million desktop computers; 3 ) 34,884-97,066 tons or 0.91-2.54 million air conditioners, and 4) 37,022-99,448 tons or 2.46-6.80 million televisions. The amount of e-waste generated in Bangkok and the provinces had a very strong positive association with household income [5].

\subsection{E-waste management flow}

According to the study of A Mangmeechai [5], Figure 1 shows the flow of the e-waste from industries and households. The e-waste from the industrial sector is not the problem because global corporations have very clear protocols for e-waste management. E-waste from these industries is transported to professional dismantling and recycling industries that often have foreign affiliates. The valuable parts, e.g., electronic circuits and batteries, are exported to foreign recyclers; for example, in Singapore and South Korea, while the less valuable parts, such as plastic, copper, iron, and aluminium are recycled by Thai industries.

In contrast, households do not have any directions or guidelines for e-waste. The collection and recycling system is not properly managed, and mainly relies on the market demand mechanism. There are four channels for household e-waste:

- The first channel is e-waste owners selling their obsolescent e-wastes to peddlers who then sell them to e-waste dealers.

- The second channel is owners donating their obsolescent home appliances to temples or non-profit organizations or associations.

- The third channel is to donate to e-waste collection projects conducted by government agencies, e.g., EGAT, universities, or private sector companies like AIS, a mobile signal provider. However, these projects are just temporary.

- The fourth channel is to discard e-waste along with household solid waste. According to a survey from the Pollution Control Department, $25 \%$ of the owners kept their obsolete electronics at home [14].

The first and second channels, the peddlers to dealers to temples or associations, often sell to second-hand markets, where such ewastes can be reused after simple repairs or upgrades. Rural populations are the major consumers for such products due to their lower incomes. These practices can be considered as an extension of the lifespans of these electronic appliances [15]. When devices can no longer be repaired, the wastes can be sold to peddlers or dealers again and later shipped to recycling industries. This process might pass many middlemen before arriving at the recycling industries. For the circuit board or battery, peddlers and dealers collect ewastes to sell to Chinese collectors who then export them to China for mineral extraction. Guangdong Province in China has the world's largest recycling center for printed circuit boards. But because the Chinese government has strengthened controls over the importing of printed-circuit boards, several Chinese firms have recently begun to recycle printed circuit boards in Mong Cai in Vietnam [16]

For the third channel, e-waste was collected and sent to professional dismantling plants (a similarly path for industrial e-waste) and recycled as part of Corporate social responsibility (CSR).

The practices in the sorting/dismantling communities, second-hand shops, etc., are not professional as workers do not have adequate and appropriate knowledge, equipment, and technologies to handle e-wastes. After collecting e-wastes, they simply employ primitive techniques, including manually dismantling electronic equipment and burning wires for steel and copper.

\subsection{The practice of informal sector and recycling industries}

The informal sectors are active in sorting and dismantling activities. They use such basic tools as hammers, wrenches, pliers, screwdrivers, grinding stones, and drills, etc., to dismantle the waste. Many workers do not wear personal protective equipment and pay more attention to economic issues than potential health problems. These communities have not yet experienced the adverse health effects of dismantling e-waste, as heavy metal illnesses are more likely to present years later than are acute sicknesses [18]. However, N Amphalop, N Suwantarat, T Prueksasit, C Yachusri and S Srithongouthai [19] confirmed that e-waste separating activities can elevate the potential ecological risk to these areas, as the researchers reported that the soil was contaminated highly with $\mathrm{Cu}$ and 
As. One research study confirmed that open burning is a common practice by informal sector used to separate the copper from the wires. that still in Thailand. The study found that increased amounts of burnt e-waste significantly influenced the concentrations of coarse and fine particles emitted [17].

For certain countries, the workers sometimes heat and remove components from printed circuit boards; cutting cables and wires for recovering metals; chipping and melting plastics; sweeping out toners; and recovering precious metals through acid leaching [15].

Thus, proper e-waste separating practices, such as operating in a closed-system workshop far from households and vegetation areas and ban open burning, are recommended highly to avoid heavy metal contamination in the soils and high concentration of fine particles.

E-waste sorting community does not fall within the definition of an industry since they use only primitive tools and have a few workers (e.g. 1 -2 family members). There are e-waste sorting communities in 17 provinces nationwide. Kalasin and Buriram provinces in the Northeastern region are the primary e-waste sorting communities and have been involved in this activity for more than 10 years. These communities operate in a way similar to an industry type 105 separation plant or landfill for waste or unused materials. For the most part, these communities' sorting and disassembling activities are just a supplementary occupation or a small business. Thus, there are no major short-term effects on the environment; instead, there are economic and social benefits to the poor communities. This is attributable to the fact that poor people undertake informal sorting and dismantling and thus the government is unable to impose a serious penalty or fines, as they cannot pay them. Open dumping of non-valuable devices is also common and has caused significant adverse environmental and health effects [1].

Industrial code 105 is licensed to sort and dismantle all kinds of wastes. According to the database system of the Department of Industrial Works, Thailand has 43 industries (involved only in e-waste) scattered in 11 provinces (largely in the Central region).

Industrial code 106 is licensed to recycle discarded industrial products or wastes, including hazardous materials and raw materials or new products. There are 116 industries scattered in 21 provinces. Most are distributed densely in the Central and Western areas, and only a few are located in the North and South.

Industry code 101 is for companies that treat or eliminate unused materials that are classified as hazardous waste. A 101 plant is a total waste treatment operation that takes one of two forms: 1) wastewater treatment plant to reduce, remove, and treat pollution contained in wastewater and sludge, or 2) waste incineration. There are 22 industries with waste disposal facilities involved in ewaste scattered in 10 provinces that are distributed largely in the Central and Eastern regions with a small number in the North and South.

\subsection{Electronic Waste Recovery and Recycling Processes}

Not all e-waste parts in the country can be recycled and different types of e-waste are transported and dismantled in different areas.

Televisions: Most televisions are sent to waste sorting communities in Kalasin and Buriram provinces that require the waste to be transported approximately 31-448 kilometers. Plastic, iron, aluminum, and copper are recycled in the country, and glass is disposed of in municipal landfills. Most of the recycling facilities are located in the Central areas. The distance between waste sorting communities and recycling facilities is as follows: copper (441-549 km); iron (112-521 km); plastic (31-518 km), and circuit boards $(523 \mathrm{~km})$. Circuit boards are exported to recycling industries abroad or burned illegally to extract valuable minerals [5].

\section{Air conditioners}

Most households that have air conditioners are located in the Central region. Thus, the discarded air conditioners are not transported to other areas for dismantling, and the distance between the waste sorting community and recycling facilities is less than $170 \mathrm{~km}$ [5].

\section{Desktop computers}

These are sent to the Suayai Uthit community (Bangkok), Daeng Yai Subdistrict (Buriram), and Khok Saat Subdistrict (Kalasin), and the transportation distance can range widely from less than 100 to $550 \mathrm{~km}$ [5].

Cellphones: It was found that phone scraps from all over the country are gathered and dismantled in three sub-districts in the Chiang Yuen District, Maha Sarakham Province. The dismantled parts can be divided into 2 groups: 1) parts that can be sold to foreign

Page $4 / 15$ 
recycling companies, e.g., batteries and circuit boards, and 2) parts that cannot be sold and are disposed of later in municipal landfills, e.g., plastic front/back cover, screens, etc. (see Tables A3-6) [5].

\subsection{E-waste management in Asia}

\section{Japan}

In 2001, Japan implemented a recycling system for TV sets, refrigerators, washing machines, and air conditioners under the Home Appliance Recycling Law. Consumers pay the recycling and transportation fees, and the discarded appliances are sent to recycling facilities. The appliances collected under this framework represent only approximately half of the estimated production, suggesting that the remaining half is either exported and/or is disposed of domestically [20].

Until 2004, there were 41 e-waste recycling facilities in Japan that the ministries, municipalities, or companies that produce electronic products financed in part. Many producers have implemented their own business strategies for e-waste management and have their own facilities, or collaborate with other producers to create and operate such facilities. e-waste derived from residences is collected when these products are no longer used or when consumers purchase new ones. The waste collected is transported to intermediate ewaste collection points (380 points) and eventually to the recycling facilities through a distribution system [21].

\section{Korea}

In January 2008, the Eco-Assurance Committee System (ECOAS) in Korea was established to re-circulate electrical and electronic equipment and vehicles in joint legislation by the Ministry of the Environment, the Ministry of Knowledge and Economy, and the Ministry of Land, Transport, and Maritime Affairs. According to ECOAS, five product groups and 27 WEEE items, including refrigerators, personal computers, electric ovens, audio equipment, and mobile phones, are controlled to increase the electronic industries' recycling capacity [22].

\section{India}

This country has implemented an EPR system since 2012. However, the system did not work because of overlap and lack of a clear target, as well the lack of a collection system. A new rule issued in 2016 added a deposit and refund system as an incentive to motivate consumers to return discarded electronic devices to their manufacturers. Those who returned their devices claimed money back with little interest. At this time, each producer has been assigned to collect $30 \%$ of the electronic devices they sold [23].

\section{Methods}

\subsection{E-waste components}

The researcher followed the methods and steps that dismantlers follow when dismantling e-waste from 1) TVs with a 20-inch color CRT screen (weighing $20 \mathrm{~kg}$ or more), 2) air conditioners, 9,000-12,000 BTU (both indoor and outdoor units), 3) desktop computers, both the central processing unit (CPU) and monitors in models between 2010-2018, 4) 4 cellphones: 1 feature phone and 3 smartphones. The main parts of the e-waste selected are separated, e.g., plastic cover, yoke, monitor, power supply, hard disk, hot coil, circuit board, motor, etc. Then, each part is weighed to calculate the percentage of the main components.

\subsection{LCA and LCC of e-waste}

An LCA and LCC study based on the international standards of the ISO 14040 series was performed. e-waste management involves collecting, disassembling, transporting, recycling, and disposing of residue [24]. The system boundaries of the LCA study of each ewaste type are displayed in Figure 1. Primary data and SimaPro software (Ecoinvent v. 3 database) were used. The method used was Eco-indicator 99 and Allocation default, and unit processes were applied to study the LCA and LCC of e-waste. 


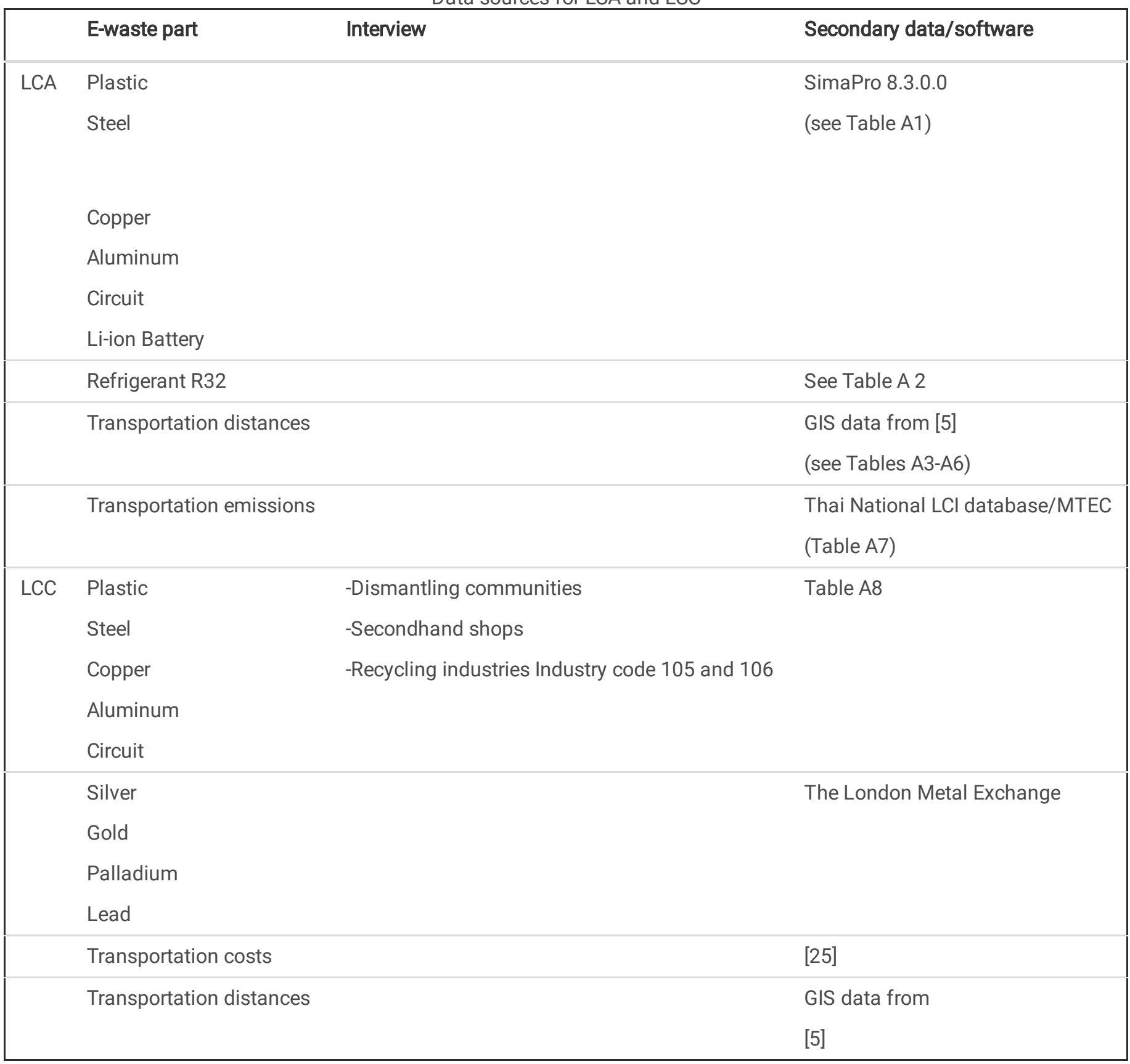

\section{Results}

\section{1 e-waste components}

The types and models of e-waste were chosen and dismantled. The separation method followed was according to informal sector practice. The e-waste components are summarized in Table 2. 
Table 2

e-waste components

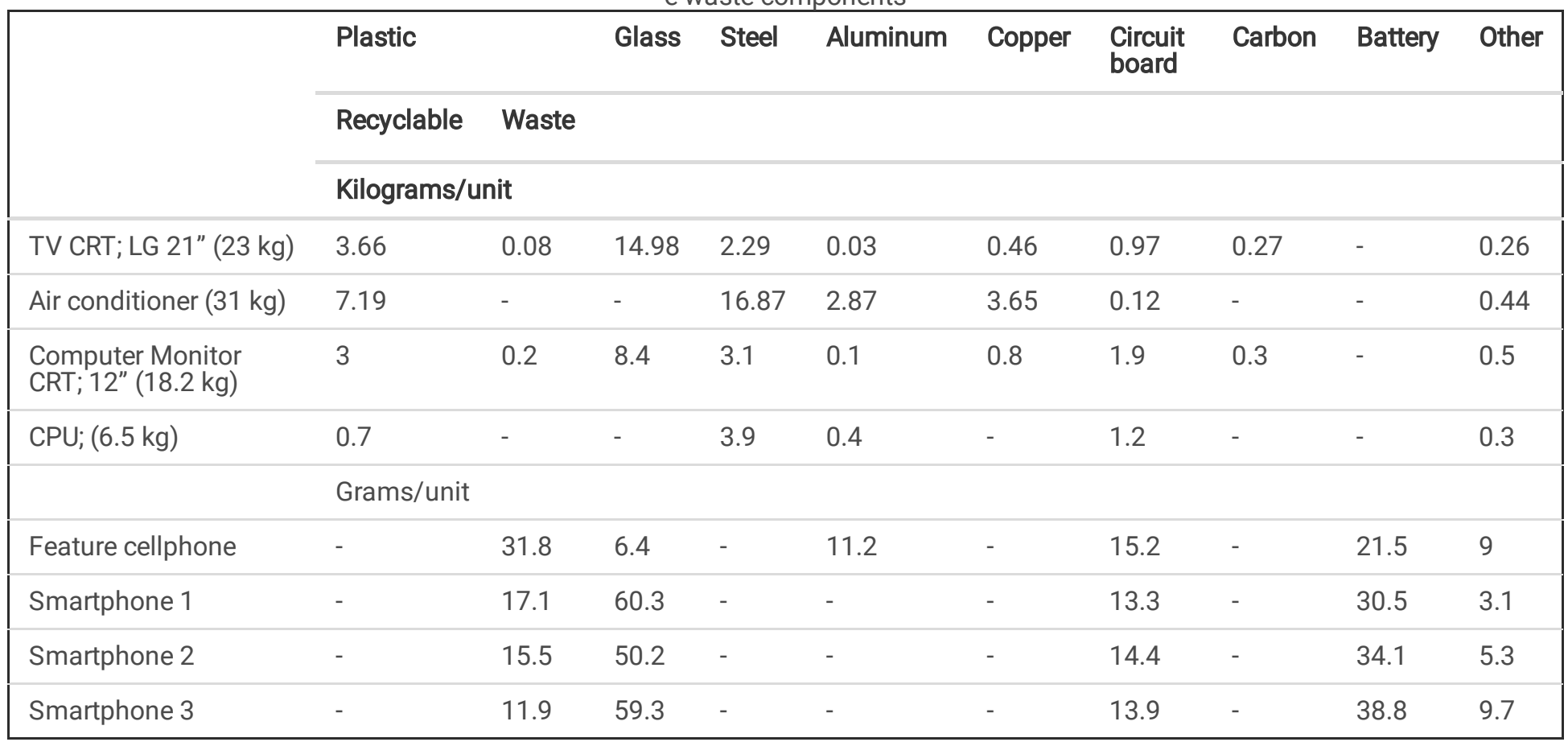

Most local authorities do not see e-waste in its original form in landfill sites [26]. Copper, steel, aluminum, and plastic can be recycled domestically. Glass from TV and cellphone screens that contains lead, and plastic (e.g., cellphones' front/back plastic case) are discarded in landfills. Batteries and circuit boards are exported for recycling to other countries, e.g., China, South Korea, and Singapore. The recyclable parts in TVs, air conditioners, desktop computers, and cell phones accounted for $30 \%, 89.9-98.4 \%, 45 \%$, and $35-50 \%$ by weight, respectively. Table 3 shows non-recyclable e-waste. TV CRTs showed the highest amount of waste, while air conditioners showed the lowest amount of waste, as most of the parts can be sold to recycling industries.

Table 3

Discarded waste from e-waste separation and dismantling

\begin{tabular}{|lllll|}
\hline & TV & Air conditioner & Desktop computer & Cellphone \\
\hline Waste (kg/unit) & 16.56 & $0.5-3.1$ & - CRT 9.4 & 0.07 \\
& & & - CPU 4.2-4.4 & \\
\hline
\end{tabular}

\subsection{LCA of e-waste}

The LCA of each type of e-waste depends upon transportation distance. The logistical system is inefficient because certain types of ewaste are transported for separation in certain areas and for recycling in another location. Most e-wastes are generated in the Central areas that have the highest household income and the majority of the recycling industries, while the dismantling communities are located in the Northeastern region because they are the poorest sector in the country. Table 4 shows the LCA of all 4 types of e-waste. The LCA is sensitive to transportation. 
Table 4

Summary of LCA of e-waste

\begin{tabular}{|lll|}
\hline E-waste type & Area & $\mathbf{k g ~ C O}{ }_{2} \mathrm{e} /$ unit \\
\hline Television & Kalasin & $0.2-3.9$ \\
\cline { 2 - 3 } & Buriram & $2.3-6.8$ \\
\hline Air conditioner & Suayai Uthit & $645-2,683$ \\
\hline Desktop computer & Kalasin & $(3.68)-0.82$ \\
\cline { 2 - 3 } & Buriram & $(2.8)-3.5$ \\
\cline { 2 - 3 } Cell phone & Suayai Uthit & $(5.1)$ \\
\hline
\end{tabular}

The country has banned the use of Hydrofluorocarbon-R22 (R22) refrigerant in air conditioners nationwide since 2018 and converted to R32, which has less effect on ozone layer depletion [27]. The amount of refrigerant depends upon the compressor size. Normal use is approximately $1-4 \mathrm{~kg}$ for air conditioners of 9,000-50,000 BTU (data from interviews with air conditioner repair shops). R32 has a GWP 675 [28]. During the process of dismantling air conditioners, the informal sector allows the refrigerant to evaporate rather than collecting it properly for disposal. Considering the emissions of the refrigerant in R32 air conditioners, it has been found that dismantling air conditioners has a negative environmental effect of (-30.1)- (-17.3) $\mathrm{kg} \mathrm{CO}_{2} \mathrm{e} / \mathrm{unit}$ if $\mathrm{R} 32$ is stored and disposed of improperly. Therefore, to reduce the adverse effects on the environment, dismantler should be encouraged to Collect R32 refrigerant rather than allowing it to evaporate.

\subsection{LCC assessment of e-waste}

The results showed that sorting/dismantling and extracting precious minerals from cell-phone waste generates the highest revenue (by weight), followed by desktop computers. The circuit boards of these two types of wastes contain precious minerals, such as silver, gold, palladium, etc. In contrast, CRT televisions generate the lowest revenue because the screen contains lead components that are hazardous substances. Table 5 shows the LCC of e-waste. 
Table 5

LCC of e-waste

\begin{tabular}{|c|c|c|c|c|c|c|c|c|}
\hline & $\begin{array}{l}\text { Dismantling } \\
\text { areas }\end{array}$ & $\begin{array}{l}\text { e- } \\
\text { waste } \\
\text { costs }\end{array}$ & $\begin{array}{l}\text { Profit from } \\
\text { selling as } \\
\text { second- } \\
\text { hand part } \\
\text { (Dismantler) }\end{array}$ & $\begin{array}{l}\text { Transportation } \\
\text { costs } \\
\text { (Dismantler) }\end{array}$ & $\begin{array}{l}\text { Profits from } \\
\text { selling parts } \\
\text { to recycler } \\
\text { (Dismantler) }\end{array}$ & $\begin{array}{l}\text { Transportation } \\
\text { costs to } \\
\text { recycling } \\
\text { industry } \\
\text { (Transporter) }\end{array}$ & $\begin{array}{l}\text { Profits } \\
\text { (Thai } \\
\text { recycler) }\end{array}$ & $\begin{array}{l}\text { Profits } \\
\text { from rare } \\
\text { mineral } \\
\text { extraction } \\
\text { (Foreign } \\
\text { recycler) }\end{array}$ \\
\hline & \multicolumn{8}{|l|}{ THB/unit } \\
\hline \multirow[t]{2}{*}{ Television } & Kalasin & $\begin{array}{l}20- \\
130\end{array}$ & & $0.5-4.3$ & $106.8-132.5$ & $0.1-3.2$ & 86 & \\
\hline & Buriram & & & $1.4-9.9$ & & $1.3-3.2$ & 82 & \\
\hline $\begin{array}{l}\text { Air } \\
\text { conditioner }\end{array}$ & $\begin{array}{l}\text { Central } \\
\text { region }\end{array}$ & $\begin{array}{l}300- \\
1000\end{array}$ & $\begin{array}{l}753.9- \\
1,375.3\end{array}$ & $0.3-2.4$ & & $1.3-4.3$ & $\begin{array}{l}368.6- \\
452.3\end{array}$ & \\
\hline \multirow[t]{4}{*}{ Computer } & Kalasin & $\begin{array}{l}100- \\
180\end{array}$ & $231.1-493.2$ & $0.2-4.6$ & $127.3-306.9$ & $2.0-7.5$ & $\begin{array}{l}111.8- \\
312.7\end{array}$ & $\begin{array}{l}470.2- \\
621.0\end{array}$ \\
\hline & Buriram & & & $1.5-10.6$ & $125.8-296.2$ & $1.9-9.0$ & & \\
\hline & $\begin{array}{l}\text { Sua Yai } \\
\text { Uthit }\end{array}$ & & & & & $0.5-0.7$ & & \\
\hline & \multicolumn{8}{|c|}{ THB / 100 units of cell phone } \\
\hline Cell-phone & $\begin{array}{l}\text { Maha } \\
\text { Sarakham }\end{array}$ & & & $0.2-18.3$ & $961.5-1,264$ & $1.4-2.2$ & & 13,089 \\
\hline
\end{tabular}

Air conditioners yielded the highest profit for Thai recyclers (by unit), followed by computers, TVs, and cell phones. In reality, if the costs of waste treatment (non-recyclable parts) are included, TV dismantlers would not make any profit. Table 6 shows a comparison of greenhouse gas emissions, added value, and waste generated from the collection, dismantling communities, recycling, and transport of the 4 e-waste products.

Table 6. LCA and LCC assessment results for each type of e-waste from the household to dismantling locations and recycling industries.

\begin{tabular}{|c|c|c|c|c|}
\hline & \multicolumn{4}{|c|}{ Type of e-waste (per unit) } \\
\hline & CRT Televisions & Air Conditioners & Desktop Computers & Cell Phones \\
\hline $\begin{array}{l}\text { Greenhouse gas } \\
\text { emissions over life } \\
\text { cycle } \\
\text { (kg CO} 2 \text { e/unit) }\end{array}$ & $0.2-6.8$ & $645-2,683$ & $(5.1)-3.5$ & $2.7-8.9$ \\
\hline $\begin{array}{l}\text { Revenue } \\
\text { (THB/unit) }\end{array}$ & $82-86$ & $368.6-452.3$ & $\begin{array}{c}111.8-312.7 \\
\text {-Extraction of precious } \\
\text { minerals: } \\
470.2-621.0\end{array}$ & $\begin{array}{c}9.6-12.6 \\
\text {-Extraction of } \\
\text { precious } \\
\text { minerals: } 130.9\end{array}$ \\
\hline $\begin{array}{l}\text { Waste } \\
\text { (Kg/unit) }\end{array}$ & 16.56 & $0.5-3.1$ & $\begin{array}{c}\text { CRT } 9.4 \\
\text { CPU 4.2-4.4 }\end{array}$ & 0.07 \\
\hline
\end{tabular}

Note: 32 THB $=1 \mathrm{USD}$

Poor $\bigcirc$ Medium Good $\bigcirc$ Excellent

Given the total e-waste generated in 2019, if all of it had been discarded and collected for recycling under the status quo, then the emissions and value-added would be as summarized in Table 7. 
Table 7

LCA and LCC assessment results of end-of-life products in 2019

\begin{tabular}{|lllll|}
\hline & $\begin{array}{l}\text { CRT } \\
\text { Televisions }\end{array}$ & Air Conditioners & Desktop Computers & Cell phones \\
\hline $\begin{array}{l}\text { Greenhouse gas } \\
\text { emissions }\end{array}$ & $0.49-46.2$ & $\begin{array}{l}598,175- \\
6,830,918\end{array}$ & $(22,822)-15,662$ & $29,009-204,700$ \\
(tons $\left.\mathrm{CO}_{2} \mathrm{e}\right)$ & & & & \\
\hline $\begin{array}{l}\text { Value added (million } \\
\text { THB) }\end{array}$ & $202.4-584.8$ & $337.3-1,151.6$ & $139-1,399$ & $74.1-285.2$ \\
& & & - Extraction of precious & $\begin{array}{l}\text {-Extraction of precious } \\
\text { minerals: }\end{array}$ \\
& & & minerals: & $1,406-3,010$ \\
\hline Note: $32 \mathrm{THB}=1$ USD & & $587-2,778$ & \\
\hline
\end{tabular}

Similar results were reported, in that the LCA study showed that recycling is not as environmentally friendly as expected, particularly when with regard to the effect of fossil fuels attributable to transportation and refrigerants [29].

\section{Discussion And Conclusions}

e-waste management is clearly ineffective and is determined by the market mechanism. In addition, workers in the informal sectors lack knowledge and tools, yet they are the main group active in sorting and dismantling waste. Thus, the e-waste management system does not meet the standard under the status quo. This research attempted to understand the trade-offs among the economic value and environmental effects of the current e-waste management system.

The study focused on four types of e-waste: cell phones; desktop computers; air conditioners, and televisions discarded in 2019. The e-waste estimates reported above can be divided into three categories according to the value of their parts: 1) waste or non-recyclable materials. For example, the non-recyclable materials are glass with lead content (TV screens), plastic, etc. which accounted for $24 \%$ of the total e-waste generated; 2) recyclable parts within the country, e.g., plastic, iron, copper and aluminum, which accounted for $70 \%$, and 3) recyclable parts outside the country, e.g., circuit boards and batteries, which accounted for $6 \%$ of the total waste.

Based upon the LCA and LCC assessment results of the 2019 waste products, it was found that the air conditioner recycling management showed the largest amount of GHGs throughout the life cycle, although it provided the highest revenue for dismantlers and Thai recyclers. However, air conditioner waste management could help reduce LCA emissions if refrigerant is disposed of properly.

The main factors that affect LCA GHGs are the transportation distances from the waste generation to dismantling areas and recycling industries. Without proper organization between the life-cycle stages, the emissions from transportation contribute a significant portion. This result is similar to that in MK Jaunich, J DeCarolis, R Handfield, E Kemahlioglu-Ziy, SR Ranjithan and H Moheb-Alizadeh [24] study, who stated that the decline in using fossil-fuel-powered personal vehicles was found to be a key contributor to cost and carbon dioxide emissions.

With respect to the LCC assessment, it was found that dismantling and recycling all four types of e-waste in 2019 resulted in income in the range of 202.4-1,399 million THB (\$6.8-\$45.0 million). The income from the extraction of precious minerals from circuit boards and batteries was in the range of 587-3,010 million THB (\$18.9-\$96.7 million USD). Although the amount from parts that are exported to foreign recycling industries is small, it has a high value after the precious metals are extracted. The extraction and recycling of circuit boards and batteries generated a higher income than Thai recycling industries.

P He, H Feng, G Hu, K Hewage, G Achari, C Wang and R Sadiq [30] showed that the LCCs of recycling one waste feature phone and one waste smartphone in China are approximately US\$ 2.34 and US\$ 6.60, respectively. The LCCs of extracting high-tech minerals, such as cobalt and palladium, from one waste feature phone are US\$ 6.035 for $1 \mathrm{~g}$ of cobalt and US\$ 0.014 for $1 \mathrm{~g}$ of palladium. The LCCs of extracting $1 \mathrm{~g}$ of cobalt, palladium, antimony, beryllium, neodymium, praseodymium, and platinum from one waste smartphone are US\$10.106, US\$ 0.024, US\$ 0.135 , US\$ 0.005 , US\$ 0.08 , US\$ 0.016 , and US\$ 0.006 , respectively. The total value added from recycling and extracting minerals falls within the same range as those in Thailand. 
It appears that the dismantling communities can earn profits from this practice; however, the reason that they gain only a slight profit is because they do not pay a landfill fee or a waste disposal fee. The local municipality covers the costs. In fact, dismantling TV CRTs costs more than its profit if the cost of e-waste disposal is included (lead contained in TV screens). Existing waste management systems should be revised to internalize disposal costs in the economy [31].

Changes in the attitudes of governments, appropriate legislation that addresses e-waste specifically, control of dumping electronic waste, implementation of EPR, and technology transfer for the sound recycling of e-waste are the keys for its effective management [32]. The Thai government has taken more than a decade to draft "The Electrical and Electronic Equipment Waste Management Act". At present, it is still in the drafting process and cannot be implemented anytime soon. Certain e-waste types may need to be charged a waste management fee because collection and recycling have more embedded costs and cannot rely solely on market determinants.

A better e-waste collection system is required, and collection guidelines and collection points will affect both profitability and GHGs. Therefore, collection, sorting, and dismantling centers by region (North, Central, West, Northeast, East and South) need to be established between dismantling facilities and recycling plants. Further, the transportation distance between each facility should not exceed $400 \mathrm{~km}$. e-waste should be considered an opportunity to recycle or recover valuable metals (e.g., copper, gold, silver, and palladium), given their significant content of precious metals compared to mineral ores [33]. In addition, a full high-tech recycling plant in the country should be promoted to achieve the complete extraction of precious minerals.

Ending informal dismantling and recycling sectors should be made one of the high-priority policy objectives for governments. Many research articles that have studied this issue also have raised this point [34,35]. The informal sector should apply the best affordable technologies and upgrade and qualify low- and medium-skilled laborers [36]. In addition, the practical feasibility of circular economy approaches and developing community commitment through stakeholders' active engagement should be promoted [37] [38].

Finally, considering the public's awareness and the human risk attitude during the e-waste recycling activities would be beneficial for organizations with respect to reducing potential adverse effects on society. Incentives may be needed to encourage people to discard e-waste at collection points and not together with their solid household waste [39]. The possible introduction of a carbon tax was also found to reduce the cost disadvantage of recycling rather than landfill disposal significantly [9]. Given the high level of environmental load associated with landfilling and the potential introduction of carbon taxes, the circular economy could be seen as a strategy to achieve appliances' sustainability. Future studies of consumers' e-waste disposal behaviour and awareness could be helpful to devise inclusive e-waste management strategies to address the current challenges [40].

\section{Declarations}

- Availability of data and material

Yes. I provided necessary data in the supplement data

- Competing interests

No

- Funding

Fully funded by the Thailand Science Research and Innovation Grand number 4450

- Authors' contributions

Field data collection, process the software, writing the whole paper

- Acknowledgements

This research was supported by Thailand Science Research and Innovation Grand number 4450

\section{References}

Page 11/15 
1. Pariatamby A, Victor D: Policy trends of e-waste management in Asia. J Mater Cycles Waste Manage 2013, 15:411-419.

2. Osibanjo O, Nnorom IC: The challenge of electronic waste (e-waste) management in developing countries. The Journal for a Sustainable Circular Economy 2007, 25(6).

3. Manomaiwiboon P: Forecast the amount of waste electrical and electronic products in Thailand and review technology for recycling abroad In. Bangkok: Industrial Waste Management Division: Department of Industrial Works; 2018.

4. Pollution Control Department: Report of the situation of hazardous waste from the community in 2019. In.: Ministry of Natural Resources and Environment; 2019.

5. Mangmeechai A: Fundamental Knowledge to Reduce Risk in Electric and Electronic Waste Management: The Trade-Off Between Economic Gain and Environmental Loss Applying Life-Cycle Assessment Method. In. Bangkok, Thailand: National Institute of Development Administration; 2021.

6. Fetanat A, Tayebi M, Shafipour G: Management of waste electrical and electronic equipment based on circular economy strategies: navigating a sustainability transition toward waste management sector. Clean Technol Envir 2021, 23:343-369.

7. Xue M, Xu Z: Application of Life Cycle Assessment on Electronic Waste Management: A Review. Environ Manage 2017, 59:693707.

8. Song X, Wang J, Yang J, Lu B: An updated review and conceptual model for optimizing WEEE management in China from a life cycle perspective. Front Environ Sci Eng 2017, 11(5):1-12.

9. Nakamura S, Kondo Y: A waste input-output life-cycle cost analysis of the recycling of end-of-life electrical home appliances. Ecol Econ 2006, 57:494-506.

10. Department of Industrial Works: Predictions for the quantity of electric and electronic appliances and the flow cycle of the waste products: Project to increase efficiency of the separation and recycling plant for waste electrical and electronic products, fiscal year 2018. In.; 2018.

11. Pollution Control Department: The estimation of e-waste : a guideline development project prepared by the Electric and Electronics Institute. In. Bangkok: Ministry of Natural Resources and Environment; 2012.

12. Pollution Control Department: Development of guidelines for assessing the quantity of e-waste. In. Bangkok: Ministry of Natural Resources and Environment; 2012.

13. Summary report for the management of the project development guidelines for the assessment of e-waste year 2012 [https://www.mofa.go.jp/mofaj._gaiko/oda/seisaku/kanmin/chusho_h25/pdfs/3a07-4.pdf]

14. Pollution Control Department: Guidelines for the waste management and hazardous substances (WEEE). In.: Ministry of Natural Resources and Environment; 2017.

15. Lu C, Zhang L, Zhong Y, Ren W, Tobias M, Mu Z, Ma Z, Geng Y, Xue B: An overview of e-waste management in China. J Mater Cycles Waste Manage 2015, 17:1-12.

16. Shinkuma T, Huong NTM: The flow of E-waste material in the Asian region and a reconsideration of international trade policies on E-waste. Environ Impact Assess Rev 2009, 29:25-31.

17. Bungadaeng S, Prueksasit T, Siriwong W: Inhalation exposure to respirable particulate matter among workers in relation to their ewaste open burning activities in Buriram Province, Thailand. Sustainable Environment Research 2019, 29(26).

18. Wassanadamrongdee S, Tanwattana P, Damrongsiri S: Results of the survey of quality of life and environment of urban slums in the occupation of e-waste separation. Environmental Management Journal 2015, 11(2):4-23.

19. Amphalop N, Suwantarat N, Prueksasit T, Yachusri C, Srithongouthai S: Ecological risk assessment of arsenic, cadmium, copper, and lead contamination in soil in e-waste separating household area, Buriram province, Thailand. Environ Sci Pollut Res 2020, 27: 44396-44411.

20. Terazono A, Murakami S, Abe N, Inanc B, Moriguchi Y, Sakai S-i, Kojima M, Yoshida A, Li J, Yang J et al: Current status and research on E-waste issues in Asia. J Mater Cycles Waste Manage 2006, 8:1-12.

21. Gaidajis G, Angelakoglou K, Aktsoglou D: E-waste: environmental problems and current management. J Eng Sci Techno/ 2010, 3(1):193-199.

22. Rhee S-W: Beneficial use practice of e-wastes in Republic of Korea. Procedia Environ Sci 2016, 31:707-714.

23. Wath SB, Dutt PS, Chakrabarti T: E-waste scenario in India, its management and implications. Environ Monit Assess 2011, 172:249-262. 
24. Jaunich MK, DeCarolis J, Handfield R, Kemahlioglu-Ziy E, Ranjithan SR, Moheb-Alizadeh H: Life-cycle modeling framework for electronic waste recovery and recycling processes. Resour Conserv Recy 2020, 161.

25. Truck data service center: Transportation costs [https://www.thaitruckcenter.com/tdsc/index]

26. Kojima M, Yoshida A, Sasaki S: Difficulties in applying extended producer responsibility policies in developing countries: case studies in e-waste recycling in China and Thailand. J Mater Cycles Waste Manage 2009, 11:263-269.

27. Rewlay-ngoen C, Papong S: Environmental impact assessment of a rotary compressor in Thailand based on life cycle assessment methodology. SN Applied Sciences 2020, 2(1526).

28. $\mathrm{CO}_{2}$ equivalents [https://climatechangeconnection.org/emissions/co2-equivalents/]

29. Garci'a AGn, Roma'n-Moguel G, Meraz-Cabrera L, Acevedo Jn: Policy options for the management of end of life computers in Mexico. Clean Technol Envir 2012, 14:657-667.

30. He P, Feng H, Hu G, Hewage K, Achari G, Wang C, Sadiq R: Life cycle cost analysis for recycling high-tech minerals from waste mobile phones in China. Journal of Cleaner Production 2020, 251.

31. Kiddee P, Naidu R, H.Wong M: Electronic waste management approaches: An overview. Waste Manage 2013, 33 (5):1237-1250.

32. Nnorom IC, Osibanjob O: Overview of electronic waste (e-waste) management practices and legislations, and their poor applications in the developing countries. Resour Conserv Recy 2008, 52(6):843-858.

33. Awasthi AK, Cucchiella F, D'Adamo I, Lia J, Rosa P, SergioTerzi, Wei G, Zeng X: Modelling the correlations of e-waste quantity with economic increase. Sci Total Environ 2018, 613-614:46-53.

34. Kahhat R, Williams E: Materials flow analysis of e-waste: Domestic flows and exports of used computers from the United States. Resour Conserv Recy 2012, 67:67-74.

35. Herat S, Agamuthu P: E-waste: a problem or an opportunity? Review of issues, challenges and solutions in Asian countries. Waste Management \& Research: The Journal for a Sustainable Circular Economy 2012, 30(11):1113-1129.

36. Widmer R, Oswald-Krapf H, Sinha-Khetriwal D, Schnellmann M, Boni H: Global perspectives on e-waste. Environ Impact Assess Rev 2005, 25:436-458.

37. Fiksel J, Sanjay P, Raman K: Steps toward a resilient circular economy in India. Clean Technol Envir 2021, 23:203-218.

38. Chakrabarty A, Nandi S: Electronic waste vulnerability: circular economy as a strategic solution. Clean Technol Envir 2021, 23:429-443.

39. Kazancoglu Y, Ozkan-Ozen YD, Mangla SK, Ram M: Risk assessment for sustainability in e-waste recycling in circular economy. Clean Technol Envir 2020.

40. Borthakur A, Govind M: Emerging trends in consumers' E-waste disposal behaviour and awareness: A worldwide overview with special focus on India. Resour Conserv Recy 2017, 117:102-113.

\section{Figures}




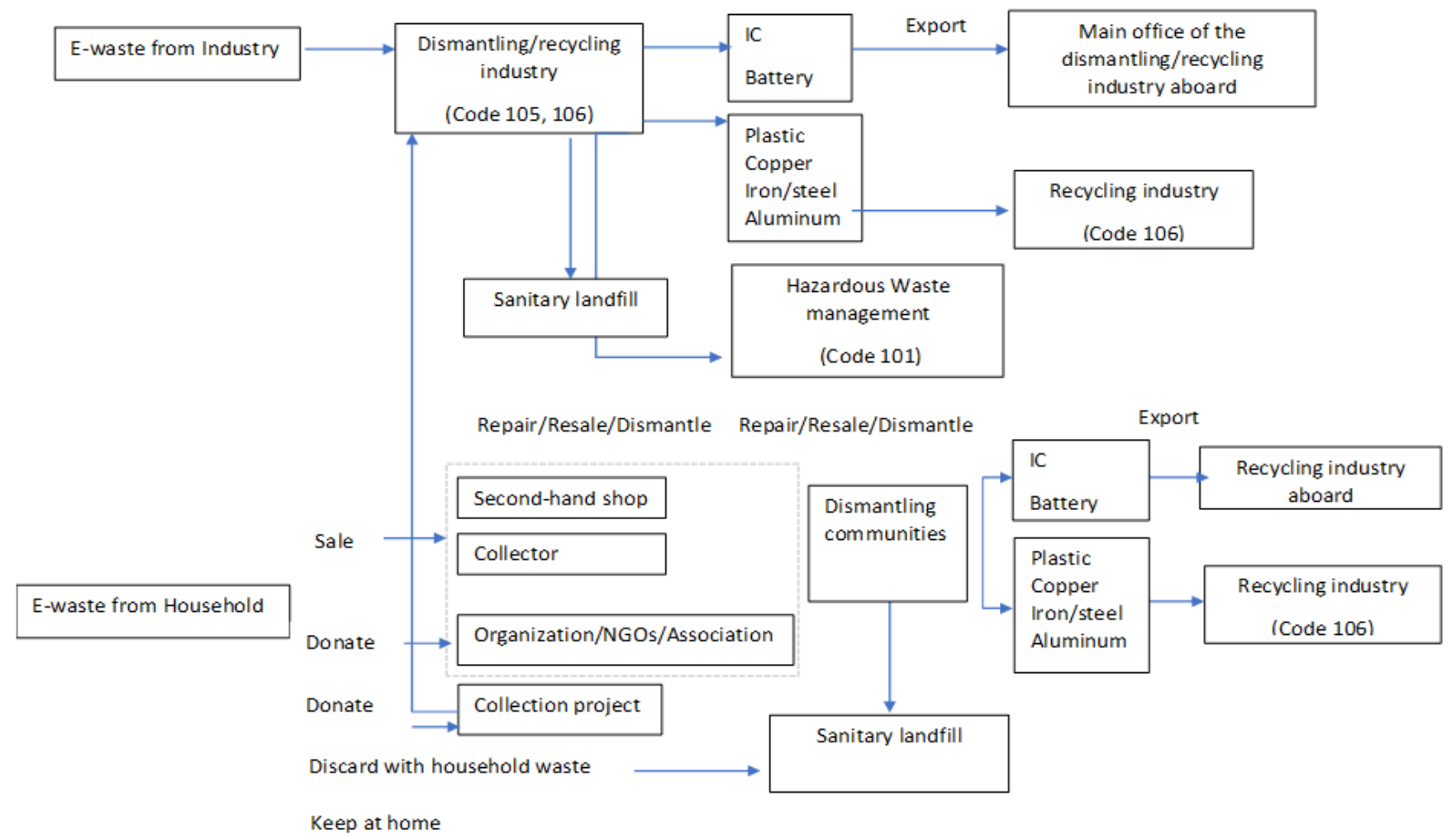

Figure 1

E-waste flow 


\begin{tabular}{|c|c|c|c|c|}
\hline & Transpo & & & \\
\hline & & Plastic & Crush & $\rightarrow$ Plastic pellets \\
\hline TV CRTs' & Dismantling & $\rightarrow \quad$ Steel & Melt & $\rightarrow$ Raw material \\
\hline $\begin{array}{l}\text { transportation } \\
\text { from origination }\end{array}$ & Industrial codes & Copper & Melt & $\rightarrow$ Raw material \\
\hline from orignation & $\begin{array}{l}\text { (Industral codes } \\
105 \text { and 106) }\end{array}$ & Aluminum & Melt & $\rightarrow$ Raw material \\
\hline
\end{tabular}

a) LCA and LCC system boundary of television CRT screens

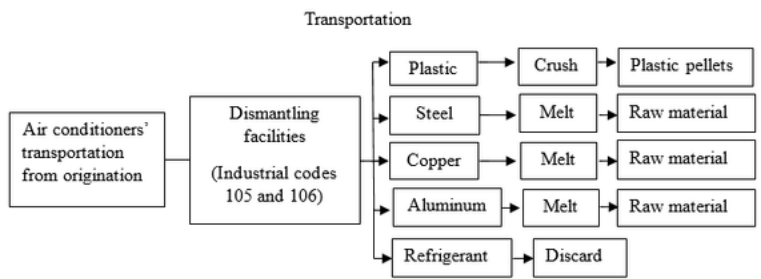

(b) LCA and LCC system boundary of air conditioners

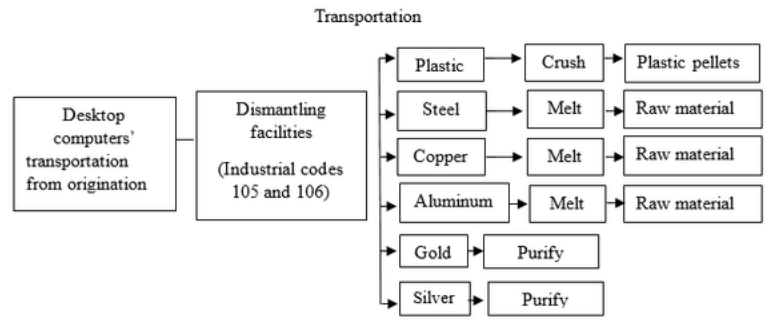

(c) LCA and LCC system boundary of desktop computers

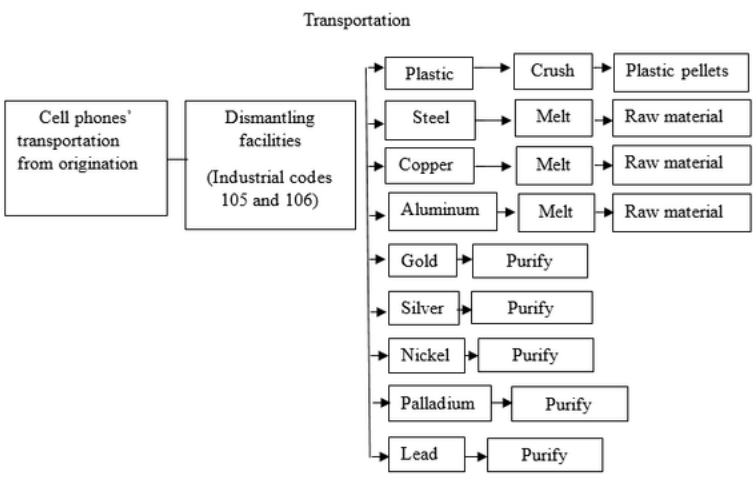

(d) LCA and LCC system boundary of cell phones

\section{Figure 2}

LCA and LCC system boundary of all four types of e-waste

\section{Supplementary Files}

This is a list of supplementary files associated with this preprint. Click to download.

- AppendixLCCLCA.docx 